\title{
Pathways of learning about biodiversity and sustainability in private urban gardens
}

\section{Diduck, Alan P.}

2020

Diduck, A P , Raymond, C M , Rodela , R, Moquin , R \& Boerchers , M 2020 , ' Pathways

of learning about biodiversity and sustainability in private urban gardens ', Journal of

Environmental Planning and Management , vol. 63 , no. 6 , pp. 1056-1076 . https://doi.org/10.1080/09640568.2019.

http://hdl.handle.net/10138/325805

https://doi.org/10.1080/09640568.2019.1633288

acceptedVersion

Downloaded from Helda, University of Helsinki institutional repository.

This is an electronic reprint of the original article.

This reprint may differ from the original in pagination and typographic detail.

Please cite the original version. 
Pathways of learning about biodiversity and sustainability in private urban gardens

First and corresponding author:

Alan P. DIDUCK

Department of Environmental Studies \& Sciences

The University of Winnipeg

515 Portage Avenue, Winnipeg, Canada R3B 2E9

Email: a.diduck@uwinnipeg.ca

$\mathrm{Ph}:+1.204 .786 .9777$

Christopher M. RAYMOND

christopher.raymond@helsinki.fi

Helsinki Institute for Sustainability Science (HELSUS), University of Helsinki, Finland

Ecosystems and Environment Research Program, Faculty of Biological and Environmental

Sciences, University of Helsinki, Finland

Department of Economics and Management, Faculty of Agriculture and Forestry Sciences, University of Helsinki, Finland

Department of Landscape Architecture, Planning and Management, Swedish University of Agricultural Sciences, Sweden

Romina RODELA

rominarodela@hotmail.com

School of Natural Sciences, Technology and Environmental Studies, Södertörn University

Robert MOQUIN

rob.moquin@gmail.com

Department of Environmental Studies \& Sciences, The University of Winnipeg

Morrissa BOERCHERS

morrissa.boerchers@gmail.com

Department of Environmental Studies \& Sciences, The University of Winnipeg 
2 Abstract

3

4 land, can provide multiple benefits, but many of these benefits are not being fully realized.

5 One reason is the normative and cognitive disconnect between people and nature,

6 highlighting the need for new learning programs to foster better nature connections. More is

7 known about learning in the context of community gardens than in relation to private

8 gardens. Using semi-structured interviews and thematic analysis, this study explores learning

9 among residents engaged in home gardening for biodiversity in Winnipeg, Canada. We

10 uncovered diverse and interconnected learning processes/activities founded on formative

11 childhood experiences. The processes/activities were non-formal and informal, and included

12 individual, social and blended experiences. Learning outcomes were also mutually

13 influencing and multi-levelled, comprising normative, cognitive/behavioural and relational

14 changes. The results support an analytical framework suggesting how learning-focused

15 initiatives can enhance biodiversity on private property and aid in delivery of nature-based

16 solutions.

17 Key words: nature-based solutions; biodiversity conservation; private gardens; non-formal 


\section{Introduction}

Urbanization continues as a global megatrend. In 2014, 54\% of the world's population lived in urban areas, with this percentage expected to increase to $66 \%$ by 2050 . This trend, combined with ongoing population growth, will add 2.5 billion people to urban centres by 2050 (United Nations 2014). Further, the impacts of urbanization on biodiversity are becoming increasingly clear. Land-cover change, loss of habitat and vegetation biomass, and other anthropogenic factors, and the self-reinforcing feedbacks among them, are contributing to reduced species, functional, structural and ecosystem diversity (e.g., Pickett et al. 2011, Seto et al. 2012, Steffen et al 2018).

Given these challenges, a major priority is to understand how urban expansion may be planned to minimise the loss of biodiversity and maintain urban ecosystem service delivery (Luederitz et al. 2015, Schwarz et al. 2017). Another is to unlock the conservation potential of blue and green spaces on private residential lands (e.g., Cameron et al. 2012, LindemannMatthies and Marty 2013, Cleveland et al. 2017, Baldock et al. 2019), particularly when faced with increasing population and housing densities (Gaston et al. 2005, Loram et al. 2007, Gaston et al. 2007). Additionally, it is clear that multi-level community engagement, including initiatives that engage, educate and empower residents (van Heezik et al. 2012, Goddard et al. 2013, Buijs et al. 2016, Mumaw 2017), is crucial to unlocking the conservation potential of private residential lands, or gardens.

Our research objective was thus to understand how learning about biodiversity in urban private gardens informs a range of cognitive, relational, normative and environmental changes, including garden management practices. We used a qualitative case study and thematic analysis to augment established methods and frameworks (i.e., van Heezik et al. 2012, Mumaw 2017, Suškevičs et al. 2017) for understanding the multiple pathways of 
43 learning, and in doing so we further elucidate the interconnections between learning and the management of private lands for biodiversity conservation.

45

\section{Problematique}

\subsection{Nature-based solutions}

Many studies have assessed the relationships among urban infrastructure initiatives, biodiversity and ecosystem services, and found that conserving and enhancing public urban blue and green spaces can positively affect resources and habitats for species of interest (Niemelä 2014), and enhance functional and structural connectivity (Iojă et al. 2014). At the same time, although the majority of biodiversity and ecosystem service relationships are positive, in some cases they can be negative, neutral or undecipherable (see: Schwarz et al. 2017 for a recent detailed review).

Similarly, private urban gardens can provide an array of supporting, provisioning, regulating, and cultural ecosystem services (Cameron et al. 2012, Lindemann-Matthies and Marty 2013, Cleveland et al. 2017), including enhanced biodiversity at multiple levels (Galluzzi et al. 2010, Sperling and Lortie 2010, Lerman and Warren 2011, Goddard et al. 2013). Further, biodiversity conservation can also have direct positive affects on cultural ecosystem services, e.g., spiritual, intrinsic, recreational and social values (Raymond et al. 2009, Freeman et al. 2012, Fish et al. 2016). The extent to which these services and benefits are realized depends on a range of factors, including garden size or vegetated area (Smith et al. 2005, Gaston et al. 2005, van Heezik et al. 2013), housing type and density (Gaston et al. 2007, Loram et al. 2007), and garden uses and management practices (Loram et al. 2011), which in turn can be influenced by socio-economic status and ability to discriminate between native and exotic species (van Heezik et al. 2013). Along with ecosystem services and associated benefits, private gardens can have, along with broader negative effects such as greenhouse gas emissions from fertilizer application (Livesley et al. 2010), direct adverse 
impacts on biodiversity, including spread of non-native and invasive species (Niinemets and Peñuelas 2008).

A paucity of studies investigate these multi-directional effects between biodiversity, ecosystem services and well-being in urban areas. To begin to address these effects, scientific investigations are now examining the co-benefits and -costs of urban green infrastructure initiatives on biodiversity, ecosystem services and human well-being under the wider banner of 'nature-based solutions' (NBS) (Raymond et al. 2017). NBS are inspired and supported by nature, bring together established ecosystem-based approaches, provide environmental, social and economic benefits and help build resilience. NBS directed towards improving biodiversity and the supply of ecosystem services, on both public and private land, can provide co-benefits for human health and well-being, water management, hazard management and air quality. However, despite this, many of these benefits are not being fully realised (see: Raymond et al. 2017 for a review). One reason for this is the disconnect between people and nature pervading western societies, which highlights that new learning programs are needed to foster better connections to nature (van Heezik et al. 2012, Beery et al. 2017).

Given the multiple co-benefits of nature connections through NBS, there are also likely to be multiple pathways of learning about them. However, little is known about how learning processes and outcomes are located in NBS, especially in the context of private garden management. This is a major gap given that NBS are seen as open innovations that require, in their design and implementation, engagement with multiple actors and integration of diverse types and systems of knowledge (Frantzeskaki and Kabisch, 2016; Raymond et al., 2017). One thing that is known is that complementary public and private action is required (Mumaw and Bekessy 2017), including community-driven initiatives that engage, educate and empower residents (Goddard et al. 2013). A crucial aspect of such initiatives is providing 
opportunities for citizens to expand their gardening skills and knowledge and deepen their understanding of, and attachment to, their local environment and the biosphere (van Heezik et al. 2012, Andersson et al. 2014, [in-text citation deleted to maintain the integrity of the review process]). In other words, learning is an essential element of the governance of private gardens in aid of biodiversity conservation and stewardship.

\subsection{Learning in environmental governance}

Learning continues to attract considerable attention in environmental governance, and is thought to be key for addressing complexity and uncertainty and for generating positive social-ecological change (e.g., Wals 2007, Diduck et al. 2012, Suškevičs et al. 2017).

Although much is known about learning and governance, important gaps remain in the literature. For example, in their recent review, Gerlak et al. (2017) identified a wealth of research questions and goals but also found lack of precision in defining learning, a need for conceptual clarity and theoretical development, little diversity in cases and methods, and a need for more rigour in assessing learning. Similarly, in their review Suškevičs et al. (2017) found rich conceptual/ theoretical diversity but also identified the need for further empirical, methodological and conceptual contributions regarding the linkages among learning, management and sustainability.

In the realm of gardening, much is known about learning in the context of community gardens. The rich community garden literature has, for example, revealed how gardening: permits collaboration and co-creation of outcomes involving different forms and systems of knowledge (Nevens et al. 2013, Frantzeskaki and Kabisch 2016); enables learning about biodiversity and ecosystem services management (Shava et al. 2010); facilitates ongoing interaction among multiple aspects of the socio-cultural and biophysical environment (Bendt et al. 2013, Krasny et al. 2013); and, can result in the development and transmission of socio- 
117

118

119

120

121

122

ecological memory (Barthel et al. 2010) and shared solutions to sustainability problems (Calvet-Mir et al. 2016).

In contrast, the literature on learning, biodiversity and private gardens is less developed. We know that programs in support of gardening for biodiversity are viewed as essential for enhancing voluntary stewardship and improving urban habitat quality (Dewaelheyns et al. 2016). The literature also shows evidence that homeowners are receptive to environmentally friendly alternatives to gardening approaches heavily dependent on exogenous inputs (Peterson et al. 2012, Lindemann-Matthies and Marty 2013, Shaw et al. 2017). Van Heezik et al. (2012) conducted one of the first studies of a learning-based intervention aimed at promoting biodiversity conservation in home gardens. Their study, involving 55 gardeners in Dunedin, New Zealand, revealed the efficacy of biodiversity appraisals, dialog, and information feedback for improving knowledge of wildlife and native species and encouraging adoption of native-friendly gardening practices. More recently, in an Australian study, Mumaw (2017) and Mumaw and Beckessy (2017) examined a program designed to improve biodiversity conservation in home gardens and advanced a stewardship development model in which different outcomes emerge at different phases. Learning by doing results in the achievement of improved stewardship behaviour during the initiation phase. In the development phase, the stewardship behaviour can, in turn, lead to a range of co-benefits such as feelings for nature, place and stewardship, the reinforcement of stewardship values and knowledge and improved stewardship competency.

In this study, we add to the nascent literature on the nexus spanning learning, biodiversity and private gardens, and respond to the calls in the broader learning and environmental governance literature for precision in terminology, more case diversity, and empirical and conceptual insights into the links between learning and management (Gerlak et al. 2017, Suškevičs et al. 2017). As noted earlier, we build on established frameworks (i.e., 
van Heezik et al. 2012, Mumaw 2017, Suškevičs et al. 2017) to further reveal how learning about biodiversity in urban private gardens informs a range of personal, social and environmental changes, including garden management practices.

\subsection{Key concepts and terms}

First, we defined learning in a broad and inclusive manner, which is important for learning embedded in garden governance. Drawing from seminal adult education literature (i.e. Merriam et al. 2007) and from a framework of multi-level learning in environmental governance (i.e. Diduck 2010), we defined learning as change in response to identifiable stimuli or information. Moreover, our concern in this study is with non-formal and informal learning (Merriam et al. 2007, Paradise and Rogoff 2009). Non-formal learning refers to learning facilitated by urban environmental education that occurs outside of formal educational institutions, such as that offered by conservation organizations, government agencies, and community-university partnerships. Urban environmental education aims to create "learning opportunities to foster individual and community well-being and environmental quality in cities" (Russ and Krasny 2017, p. 288). Informal learning refers to the experiences of everyday living from which people learn something; it is learning through observation, participation and self-directed knowledge creation.

\section{Research design}

We took an exploratory and inductive approach (Creswell 2014), preparing a qualitative case study of non-formal and informal learning (by gardeners) about biodiversity conservation in private gardens in the Canadian city of Winnipeg. Winnipeg is illustrative because it is home to Naturescape, a longstanding education and certification program aimed at increasing biodiversity in private gardens introduced and overseen by FortWhyte Alive an environmental education centre in southwest Winnipeg (FortWhyte Alive 2017).

\subsection{Background to the case}


Winnipeg, the political capital and economic centre of the Province of Manitoba, is the seventh largest city in Canada, with a 2016 population of 705,244, population density of 1,519 per $\mathrm{km}^{2}$, and an area of $464 \mathrm{~km}^{2}$. The average age of the population is 39.9 years, the majority of homes are single-detached houses (59.4\%), and the average household size is 2.5 people (Statistics Canada, 2017). Winnipeg is located at the eastern edge of the northeast North American plains. The soil in the area is typified by heavy lacustrine sediment upon which periodic riverine flooding helps create exceptionally fertile soils (Smith et al. 1998). The regional climate is characterized by short, warm summers and long, cold winters. The annual mean temperature in Winnipeg is $3.0^{\circ} \mathrm{C}$, with a daily average of $-16.4^{\circ} \mathrm{C}$ in January and $19.7^{\circ} \mathrm{C}$ in July. The region receives between 85 and 120 frost-free days, on average. The mean annual precipitation is $521.1 \mathrm{~mm}, 418.9 \mathrm{~mm}$ of which is rainfall (the remainder snow). The majority of rainfall occurs in June through August (Environment Canada 2018). FortWhyte Alive is a 630 -acre environmental education centre in southwest Winnipeg. In 2016, it had 25 full-time staff members, 505 volunteers, and a budget over $\$ 2,500,00$. One of its programs, Naturescape, aims to enhance biodiversity and increase habitat for native flora and fauna in private gardens. The program offers an array of nonformal education activities for home gardeners, most of which occur at FortWhyte. The activities include presentations and workshops on subjects such as pollinators, composting, creating habitat for insects, birds and wildlife, and organic gardening. The program also provides guidance and advice to gardeners via the telephone and online (FortWhyte Alive, 2017). Naturescape attracts gardeners who are sustainability-minded and who have an interest in protecting and enhancing biodiversity ([in-text citation deleted to maintain the integrity of the review process]), and it also offers incentives to its participants, including discounts at the FortWhyte store and local garden centres. A further incentive is that participants whose gardens meet certain biodiversity-related criteria, such as planting native species, creating 
192

193

194

195

196

197

habitat, providing year-round food sources, and avoiding biocides, receive a "Naturescape certified" garden sign for displaying in their garden.

\subsection{Semi-structured interviews}

Our primary method was semi-structured interviews. Using a purposive approach (Creswell 2014), we selected participants who were actively engaged in home gardening for biodiversity conservation or restoration of native plants and animals. We recruited 33 participants from among the Naturescape certified gardeners (after FortWhyte obtained permission for us to contact them) and another 17 using a snowball approach, which involved asking the "Naturescapers" to introduce us to people who, while not Naturescape certified, had gardening practices similar to their own. Overall, forty-two (42) interviews were conducted in April and May 2017 (covering 42 gardens), each lasting between 30 and 60 minutes. Most of the interviews were conducted in the participants' home or garden, with four being done at FortWhyte and one via telephone. Prior to, or following, each of the interviews at the participants' residences, we viewed and photographed the gardens. Each interview was audio recorded and transcribed verbatim. Most interviews $(\mathrm{n}=$ 35) were conducted with individuals, while the balance were with couples $(n=6)$ and in one case a family of three. The interview guide had 27 questions and prompts, and was divided into six main parts, which delved into demographic and garden characteristics, learning activities or processes (i.e., how learning occurred), learning outcomes (i.e., what was learned), and other personal, environmental and social benefits resulting from gardening. This paper focuses on the learning questions, but also includes learning-related data obtained in response to the benefit questions.

\subsection{Analysis}

We used inductive, or grounded, thematic analysis (Corbin and Strauss 2014, Creswell 2014), using codes and seeking themes and sub-themes (related to learning 
217 activities/ processes and outcomes) that were grounded in the language and ideas of the 218 interview participants. Using NVivo 12 qualitative analysis software, we did four rounds of 219 coding (open, axial and thematic), encompassing both non-formal and informal learning. For 220 each individual code we collated all data segments (instances of text) where that code appeared in the dataset, and themes were ultimately developed when codes clustered together. Presence or absence of data was then recorded for each theme, or sub-theme, together with the number and percentage of interviews clustered at each particular theme. In keeping with thematic qualitative analysis, predominance was not the sole measure of thematic significance; the importance of minority viewpoints was also considered.

To assist with trustworthiness, we held a verification meeting with research participants in September 2017 in which we distributed a plain language summary of the research, presented the preliminary results, and facilitated a discussion about the results. The results are represented in Section 4 by direct quotations from the interviews. To save space, we selected the one, or sometimes, two quotations that best represent the findings. To protect anonymity, we assigned code names to the participants.

\section{Results}

\subsection{Demographic and garden characteristics}

The research participants were generally older, more formally educated, and came from higher income households than others in Winnipeg (Statistics Canada, 2016), and most had been living in their homes for relatively long periods of time. The average size of their properties was larger than the typical lot (parcel) size in Winnipeg $\left(465 \mathrm{~m}^{2}\right)$ (Pers. Comm. Winnipeg Realtors 2018), and their gardens were located in both back and front yards as well as alongside the house. By way of summary:

- $74 \%$ of the participants were over the age of $50(\bar{x}=59)$;

- $70 \%$ were female; 
- $\quad 42 \%$ were retired;

- $66 \%$ had college or university degrees;

- $20 \%$ were involved in education, law and social, community or government services;

- $14 \%$ were engaged in business, finance or administration;

- $67 \%$ had been living in their homes for more than 15 years $(\overline{\mathrm{x}}=21)$; and

- property sizes ranged from 149 to $9,239 \mathrm{~m}^{2}(\overline{\mathrm{x}}=1,211)$.

\subsection{Learning activities or processes}

The analysis yielded six interrelated, non-mutually exclusive, primary themes about learning activities or processes (i.e., how learning occurred): 1) childhood experiences; 2) practice; 3) workshops, classes and conferences; 4) resource material; 5) talking with gardeners; and 6) observation. Five of the primary themes include secondary themes and, in one case, tertiary themes. Table 1 identifies the themes and, to show their predominance, includes the number and percentage of interviews that provided evidence regarding each theme.

\section{INSERT TABLE 1}

\subsubsection{Workshops, classes, conferences}

The predominant primary theme was workshops, classes and conferences, referenced in $88 \%$ of the interviews. These learning activities were sponsored by universities, the city, churches or conservation organizations (36\% of the interviews), the Manitoba Master Gardener Association (21\%), garden clubs, societies or nurseries (17\%), and Naturescape/FortWhyte (62\%), and covered a host of topics, such as butterfly gardens, compost tea, container gardening, medicinal plants, moon gardening, native species, and pest and disease control. 

and attending workshops or classes. In contrast, in $40 \%$ of the interviews (or $61 \%$ of the

Naturescape interviews) people said they had not attended educational events but simply applied for certification. Janis said, "No I haven't done any of the workshops or the volunteering; it's yeah, really just the certification side." Bonnie reported, "I haven't been to any of the offerings of Naturescape, because in a sense I know a lot of that stuff. I've spent a lot of time at FortWhyte, apart from that, so I don't need to go back for more."

\subsubsection{Childhood experiences}

In $74 \%$ of the interviews, participants traced how they learned about gardening to formative childhood experiences. For example, Joni said, "I grew up with it. I've been a farm kid. It's just something you did. I mean, you just planted your garden in the springtime; you did the harvesting over the course of the summer and fall. So, it's just always been a part of me." Similarly, Grace reported that, "When I was a kid my mum had a big vegetable garden and I always had my little couple of rows at the end that I could plant whatever I wanted in so I guess that's where I first got the gardening bug." Janis put it this way: "I mean it was kind of always around, but it wasn't like "Come into the garden with me". So, osmosis. Is that a good answer?”

\subsubsection{Practice} error (50\%). For Mick, "You just have to kind of learn and experiment as you go and figure out what is going to work in your space and for the things that you are growing." Similarly, in

Learning through practice was another common primary theme (74\% of interviews). Participants often expressed themselves in terms of experimentation, exploration or trial and many interviews (48\%) participants spoke in terms of learning by doing. When asked how 
certain things wrong." Volunteering in the community (24\%) was another important process of learning through practice: "I've been involved with [Nature Manitoba] since long before we moved here. So, I built up a good knowledge of native plants, especially native prairie plants, and I just wanted to grow some of them" (Diana).

\subsubsection{Talking with gardeners}

Talking with gardeners was the fourth most common primary theme (43\%), and its two predominant secondary themes were technical experts and friends and peers, both of which were referenced in $26 \%$ of the interviews. Regarding technical experts, Dolores described the following experience when asked why she began gardening: "There were some botanists in the room who would talk about native plants and then we started talking about putting in flower gardens and the ideas just bloomed one after the other with what to plant. And not just to do hybrid perennials that are on the market but to put in something that wildlife will benefit from as well and things that we can harvest food from."

About friends and peers, Van had the following to say when asked how he learned how to garden: "I learned from just gardening and trying a whole bunch of stuff and meeting people and learning from community members and friends. I think it is an invaluable resource to try to learn as much from people as possible. I don't think there is a right or wrong way [to garden]. Some things are going to work better than others and some people have methods they've used for many years and it's always worked perfectly for them.”

\subsubsection{Resource material}

Resource material was another primary theme ( $40 \%$ of interviews), and included the Internet (10\%), brochures and pamphlets (7\%) and generic references to reading $(7 \%)$.

Books and magazines was the predominant secondary theme (31\%). Keith said, "I've got tons of books and all kinds of stuff that I could always find something on”. Eric talked about, “...a magazine called Harrowsmith - maybe it is dead now - but they had some articles about 
gardening that really caught my fancy. I read some articles about wildflowers and I really thought it was cool".

\subsubsection{Observation}

The sixth primary theme dealing with learning activities or processes was observation (24\% of interviews), which includes watching family (10\%) and garden tours and field trips (14\%). About the former, Ronnie said he first learned to garden "from my grandmother, my baba. Just from observation." Regarding the latter, George and Patti said: "We had gone on a garden tour and we saw a yard that had that [Naturescape] sign and we were curious about it, what that meant. And then I think [Patti] tripped across it maybe at FortWhyte and then we sort of got the application and looked at it and said oh that's really cool and thought, gee, we're really close [to qualifying for certification]."

\subsection{Learning outcomes}

We found three primary themes about learning outcomes (i.e., what was learned): 1) normative; 2) cognitive or behavioural; and 3) relational. The primary themes were interconnected and not mutually exclusive, and each contained secondary themes and, with one exception, tertiary themes (Table 2).

\section{INSERT TABLE 2}

\subsubsection{Normative}

\subsubsection{Personal fulfilment or identity. Evidence regarding normative changes, i.e., changes} relating to norms, standards or ethics, was found in all the interviews. The predominant secondary theme was personal fulfilment or identity ( $76 \%$ of interviews), which included general comments such as Carole's statement that gardening is "a whole undertaking and part of our lifestyle and what we get excited about." Personal fulfilment or identity also consisted 
of four tertiary themes, the two most prominent of which were mindfulness, reflection or relaxation (45\%) and happiness, gratification or creativity (26\%). Regarding the former,

Charlie said gardening has helped him clarify what is important in his life, "everything from a spiritual sense - not in the sense of religion - to an ethical sense of understanding all the life forms or not understanding all the life forms." With respect to happiness, gratification or creativity, Diana reported that, "When I see things doing well, when I see birds using trees and shrubs that I've planted, it's hugely gratifying.” About her garden, Linda said, “it's my creative side that I can release there." The remaining tertiary themes pertained to gardening helping people develop a sense of home (17\%) and giving them direction, motivation or purpose in life (12\%).

\subsubsection{Nature connections. The second most prominent normative theme was nature} connections, including greater appreciation for land, nature and plants (74\% of interviews). Here, as above, people sometimes spoke in general terms, e.g., "[Gardening] connects us to the land. We have planted prairie so it is sort of a reminder of our place here on the prairies" (Mick). Additionally, specific connections coalesced around three tertiary themes, the two most prominent of which were wildlife and birds (45\%) and biodiversity (29\%). The first of these pertained to increased enjoyment of outdoors, and in particular attracting and viewing wildlife and birds. For example, Carole said, "We're also really excited to see what birds we get and what critters we get. Last year, I woke up to this horrible ruckus. I'm like, "What is going on outside?” And I look outside the window and that squirrel buster that I told you about, we used to have it back there, hanging on the fence, and we looked and a giant raccoon had taken it and was just shaking it like this."

The biodiversity sub-theme encompassed general comments as well as references to specific aspects of biodiversity, namely native species, habitat and pollinators. An example is Bonnie's comment that for her gardening has reinforced the importance of "providing habitat 
for endangered species, for both migratory species, and also for species that live here whether it's insects or for birds." The remaining tertiary theme encompassed greater recognition of the balance or beauty (12\%) of nature.

\subsubsection{Environmental consciousness. Another prominent normative theme, environmental} consciousness (67\% of interviews), was reflected in both general comments, e.g., "[Gardening] has made me aware that we really have to be more environmentally conscious" (Keith), and in specific references grouped by tertiary themes. The two most common themes were environmental protection or conservation (24\%) and stewardship (24\%). With regard the first of these, Etta said, "I did use some sprays years and years ago, early on when I first got started. But I've come a long way and I do not want anything to do with chemicals, because I mean it's not good for the environment, it's not good for me, for people." Stewardship involved a sense of responsibility for the land or a desire to give something back to nature, as seen in the following comment: "I guess what working on this yard and converting it from basically a blank piece of lawn to this chunk of habitat, has made me realize how important it is to look after a piece of [land] no matter how small or how immersed in an urban environment" (Diana).

4.3.1.4. Engaging with community. The fourth secondary normative theme pertained to how gardening helped people clarify the importance of engaging with community ( $21 \%$ of interviews), e.g., "I think that gardening should not be limited just to the home yard but the whole community. For example, boulevards, why do we only grow grass on boulevards? There are people who are hungry and people who need vegetables. Why don't we encourage people to plant a garden on the boulevard and then donate or share it? Gardening should be something that unifies and is broader than just the individual homeowner" (Johnny and June). This theme included a tertiary theme regarding teaching or helping others (12\%), e.g., "I always trust and believe in gardening and also I'm more interested in teaching young minds 
because I see that the new generation is way away from gardening or nature" (Bob, Sara and Jakob).

\subsubsection{Cognitive or behavioural}

\subsubsection{Nature. We found evidence of cognitive or behavioural changes in all of the} interviews. The predominant secondary theme was nature (93\% of interviews), which included four tertiary themes. Ecosystems (69\%) was predominant and covered three broad aspects: habitat, shelter and food; pollinators (butterflies, bees, bats); and ecological connections. Talking about Naturescape, Courtney said, "What I've taken away from it is to try to keep things as natural as possible, so I don't clear everything out in the fall. I don't clear up all the leaves or the brush; I leave places for birds and frogs and toads to shelter." Plants (53\%) was the second most prominent tertiary theme, covering basic biology, a wide array of species, biodiversity, native species and heritage species. For example, in answer to what he has learned through gardening, Mick said, "Another thing is just the structure of plants, like how things grow. I couldn't really give you specifics about that but paying attention to when the potato plant flowers or pulling up a raspberry plant and looking at the roots and figuring out the root connections." Regarding biodiversity, Bonnie said, "I've become much more conscious of the endangered prairie ecosystem, as a whole, and of the diminishing acreages of tall grass/mixed grass prairie and of the species that find their home on that land."

Birds (45\%) was also a prominent tertiary theme, comprising species diversity, biology, behaviour and feeding. For example, in speaking about Naturescape, Carly said, "I've tried a number of things to attract certain birds, like orioles. Having certain colours out there, having certain types of food for them; I've learned that through Naturescape." Talking about his garden, Elvis said, "The birds usually are out there [in the garden] and so I know how the different birds are going to respond. Some fly away, some hang around." Outdoor 
413 living and nature observation (31\%) was the final tertiary theme, capturing activities that take

414 advantage of the benefits of having garden, e.g., bird watching and socializing.

415 4.3.2.2. Gardening. Another notable secondary theme, gardening ( $83 \%$ of interviews), was

416 made up of four tertiary themes, the predominant one being management (69\%). This theme

417 covered composting, mulching, organic approaches, soil conservation and water

418 conservation. Stevie said the following about water: "I'm a little more conscious, maybe, of

419 the water sources, keeping a damp spot for butterflies and so on. We've got a couple of bird

420 baths and the pond, so we've always had a water feature". Carole discussed her organic

421 approach to pest control: "We actually had an inundation of aphids on our plum. So, instead

422 of spraying it, we just bought a whole bunch of ladybugs and let them go, and that took care

423 of our problem. It was a really cool idea to use something natural like that, and it worked like

424 a charm".

Design (38\%) and methods (36\%) were two additional tertiary themes. The former includes companion gardening. For example, Aretha said, "I go to [workshops or classes] to learn about plants, communities and more like the ecology of this type of gardening because I think this is fascinating. What shall we grow together, what thrives together and that's what I learned from these organizations."

Methods covers day-to-day routines, such as pruning, weeding and deadheading along with seasonal routines, such as seed saving and planting seedlings. In contrast to those who emphasized environmental protection or organic methods, in three interviews people indicated that their gardening experiences led them to realize that using pesticides is

434 sometimes necessary, e.g., "Some people are absolutely drug free, nothing, no chemicals, 435 nothing in their yard. But they're people who don't have a life and they like to sit there all 436 day and pick the damned lily beetles. I work for a living, so I have to spray them” (Keith). 
437 Challenges (14\%) was the final tertiary theme of gardening, largely reflecting concerns about

438 the effects of climate change on growing seasons and plant hardiness zones.

\subsubsection{Validation or empowerment. The final secondary theme, validation or empowerment} ( $40 \%$ of interviews), captured suggestions that gardening or being involved in Naturescape validated people's understandings or practices. As an example, Bonnie said, "I love the idea that [Naturescape] is encouraging people to see their garden as a haven for wildlife, to garden responsibly. And for me, it was important to be supporting that and to have what I've done here validated in some kind of way." Along the same lines, Lucinda stated, "It gave me courage to really focus on tall grass and to be brave with that. It gave me confidence to do that. Yeah, that's really important."

\subsubsection{Relational}

\subsubsection{Community building. We found evidence of relational changes in 40 of the 42} interviews. The predominant secondary theme was community building ( $81 \%$ of interviews), which included four tertiary themes. In $48 \%$ of interviews, people discussed how gardening or being involved in Naturescape influenced their friendships through development of shared interests in nature (48\%). For example, Elvis reported, "I have one friend who gardens. She's English and she likes to do it in traditional manner but I've introduced her to some native shrubs and other plants and I think she's altering her habits a little bit." Forty eight per cent (48\%) of interviews also revealed evidence of reciprocity or gifting, e.g., "[Gardening] has changed our relationships with our neighbours. We will give some produce to our neighbours if we have extra. Sometimes our produce grows over the fence so we say, just help yourself to whatever grows on the other side of the fence" (Mick). Further, in $24 \%$ of interviews, participants discussed how gardening or Naturescape enhanced friendships, e.g., "Working with gardens has helped [Niko] and I become better friends, because we have something in 
common that we both love" (Mavis). In another 24\%, people revealed how they made new acquaintances because of their garden. For example, Janis said, "There's a lot of community interest and people introducing themselves and asking questions in that way."

\subsubsection{Family bonding. Yet another notable secondary theme was family bonding ( $64 \%$ of} interviews), which encapsulated two tertiary themes. Similar to the theme of community building, people discussed how gardening or Naturescape influenced their family connections through the development of shared interests and activities (50\%). "My husband and I have grown into gardening and grown to being excited about nature in our backyard together" (Carole). "My brother and I have become a lot closer, and found something to talk about - a shared interest" (Paul and Linda). Several interviews referenced that gardening evoked fond family memories or sentiments (21\%), e.g., "I've got a bleeding heart that belonged to my dad and I mean that thing's - like he's been gone, he died in ' 88 but I still have the perennial. So it's a continuation of life almost" (Billie).

4.3.3.3. Civic engagement. Another noteworthy secondary theme was civic engagement ( $43 \%$ of interviews), which included three tertiary themes. Nine interviews (21\%) revealed evidence of new or wider networks, e.g., "I have another whole community now when I got involved with [XYZ Garden Club]. I'm now good friends with a couple of excellent gardeners. Socially has it changed me? I guess that's it (Gladys). A further $21 \%$ of the interviews referenced volunteering for a gardening, conservation or other community organization. For example, Aretha explained that her gardening experiences led her to volunteer at [XYZ House] taking care of its raised garden beds, "mostly container things and being available to the families who stay there because they have a sick child in the hospital". Finally, in eight interviews (19\%), people discussed how gardening or Naturescape, has led them to engaging in advocacy. For example, with respect to the Naturescape sign, George and Patti said, "Because we live in a suburban landscape we always make jokes that we are 
486

487

488

489

490

491

492

493

494

495

496

497

498

499

500

501

502

503

504

505

506

507

508

509

the neighbourhood hippies so we wanted to put that sign out and show people that this yard isn't a mess. It's intentional and that they could try new things other than just grass and lawn surface."

4.3.3.4. Conflict or isolation. The final secondary theme was conflict or isolation ( $29 \%$ of interviews), which stood in contrast to the building and bonding themes noted in Sections 4.3.3.1 and 4.3.3.2. Several people commented on how gardening for biodiversity created conflict with their neighbours. Annie discussed being the subject of multiple nuisance complaints by her neighbours because of her seemingly untidy garden. Lucinda reported a similar experience. In three interviews, people (Diana, Carly, Janis) noted how their neighbours think they are "weird" or "crazy". Chrissie summed it up like this: "I think the biggest problem I have is that permaculture and its whole philosophy is so contrary to conventional life in North America and certainly conventional gardening practice, and so I feel at odds all the time.”

\section{Discussion}

From the results we conceptualised a multi-layered analytical framework outlining pathways of learning about biodiversity and sustainability in private urban gardens that combines both processes / activities and outcomes (Figure 1). The framework is underpinned by two guiding principles.

\section{INSERT FIGURE 1}

\subsection{Learning processes / activities are mutually influencing, multi-leveled and both non-}

\section{formal and informal}

Figure 1 presents interconnected learning processes / activities founded on formative childhood experiences (section 4.2.2). The processes / activities include both non-formal (4.2.1 - workshops, classes, conferences; 4.2.5 - resource material) and informal types (4.2.3 
510 - practice; 4.2.4 - talking with gardeners; 4.2.6 - observation). Further, they are multi-

511 levelled in the sense that they include highly individual (resource material) (the dark grey

512 circle in the processes / activities box of Figure 1), highly social (workshops, classes,

513 conferences; talking with gardeners) (the white circles) and blended individual / social

514 (practice; observation) (the light grey circles) experiences. The left-to-right feedback arrow

515 represents the influences that processes / activities have on outcomes, as reported by the

516 research participants.

517 The framework builds upon important insights from the informal and non-formal

518 learning literatures. It supports earlier research where formative informal childhood learning

519 experiences were found to have an impact on recreational and environmental preferences,

520 interests, and attitudes later in life (e.g., Fisman 2005, Bourke et al. 2018). It also establishes

521 the importance of such experiences in relation to gardening for biodiversity and

522 sustainability, particularly when combined with multiple informal and non-formal adult

523 learning processes / activities.

524 While we assumed that Naturescape's non-formal learning programs would be a

525 primary influence on learning outcomes, we found that other non-formal events (e.g., those

526 organized by garden clubs, societies or nurseries - 4.2.1) and a wealth of informal processes /

527 activities (i.e., practice, dialogue and observation) were just as influential, or perhaps more

528 so. The framework thus illuminates the importance of, and the linkages among, non-formal

529 learning events, practice, dialogue (i.e., talking with gardeners), observation, and individual

530 study / reflection (i.e., engaging with resources). This diverse bundle of processes / activities

531 might be indicative of a meaningful search learners put in place for a type of exchange and

532 learning opportunities from which they can benefit in terms of gardening for biodiversity

533 conservation. 

network with which they interact. Moreover, it does so in the specific context of gardening for biodiversity and connects learning opportunities gardeners develop on their own (i.e., with hands-on practice, observation, and engagement with resources) with learning opportunities gardeners experience during interaction with others / like-minded people (i.e., attending events, workshops and talks and exchange with gardeners). This sheds light on the processes / activities that could play a role in learning at different levels of social aggregation (i.e., individuals, groups, organizations, etc.), which continues to be an under explored question in the environmental governance and learning literature (e.g., Gerlak et al. 2017).

\subsection{Learning outcomes are multiple (normative, cognitive / behavioural, relational),} mutually influencing, and encompass feedbacks with the processes / activities that support them

Figure 1 shows that, similar to processes / activities, the learning outcomes (4.3.1 normative; 4.3.2 - cognitive / behavioural; 4.3.3 - relational) are interconnected. An example is the clear overlap among greater appreciation for land, nature and plants (4.3.1.2), better understanding of ecosystems (4.3.2.1) and development of shared interests in nature (4.3.3.1.). As well, the outcomes are multi-levelled in that they include largely individual (normative) (the dark grey circle in the outcomes box of Figure 1), largely social (relational) (the white circle), and blended (cognitive / behavioural) (the light grey circle) experiences. Further, they are multi-levelled in the sense that by spanning cognitive / behavioural, normative and relational change they encompass different aspects of a person's meaning perspective. The right-to-left feedback arrow represents that learning outcomes influence 
processes / activities. The two feedbacks depict that learning was continuous, iterative and dynamic, as suggested in the results.

The broad types of outcomes (normative, relational and cognitive / behavioural) we

found resonate with what others working with social learning in natural resource management have reported before (for a review: Rodela 2014). The novel contribution of our framework is that learning outcomes are not laid out in the abstract but are contextualised to biodiversity, sustainability and urban gardens, which then allows assessment and collection of evidence about each. Further to this, having these outlined may help to fine tune the design and delivery of future programs which aim to perform as a (non-formal) learning intervention targeting urban gardeners and to that end structure activities at different levels (individuals, groups, organizations) meant to best address issues and needs present in that area.

The framework is consistent with the observation by Suškevičs et al. (2017), who noted that natural resource and environmental managers develop a sense of direction for their own learning that is influenced by social networks. Our study builds on that by highlighting that a wider social and institutional context influences strategies gardeners adopt when navigating different learning opportunities available to them, and how that context then influences their choices about gardening. Our study, although encompassing a wider array of learning processes and outcomes, also aligns with the study by van Heezik et al. (2012), who showed the effectiveness of garden appraisals, dialogical non-formal learning activities, and information feedback for enhancing capacity for biodiversity gardening. Additionally, our work is consistent with Mumaw's (2017) stewardship development model of non-formal learning for biodiversity conservation in home gardens. A point of distinction is the extent to which our framework highlights formative childhood learning experiences. Another is our framework's emphasis on informal learning and multiple and diverse non-formal learning 
processes / activities. This emphasis is consistent with Heimlich et al.'s (2017) observation about the wealth of non-formal environmental education programs found in many cities. Another contribution of the 'pathways of learning' framework is the direction it offers for future research, such as testing its applicability among gardeners who were less interested and involved in gardening for biodiversity than were our participants. The people in our sample were noticeably sustainability-minded and highly motivated to protect and enhance biodiversity in their gardens. A sample with different formative childhood experiences, and less access to learning activities/ processes, might have revealed different types of learning outcomes. Other promising avenues of further research include identifying the most effective NBS policy and governance measure for promoting biodiversity conservation initiatives across private and public lands and exploring how learning-based initiatives can be used to advance biodiversity conservation at the landscape scale. Further, there is a need to apply different research designs and methodologies, such as longitudinal studies, mixed methods and narrative-based constructivist approaches, so we can build theory through both deep understanding of learning pathways and generalizable results across individuals and groups, and across time.

\section{Conclusions}

This research reveals the extent to which learning about biodiversity and sustainability in private urban gardens is multi-form, multi-layered and dynamic. It adds to the literature interested in the nexus between learning, biodiversity and private gardens by providing descriptive evidence about individual experiences conducive to learning, including contact with nature, contact between different individuals and groups, and other activities and sources. The study also finds how this involves varied cognitive, behavioural, relational and normative changes that emerge in an iterative and ongoing fashion at different parts of the various pathways. As well, these changes are not only associated with one nature-based 
607 solution or learning program but are constituted in a larger socio-ecological context. These

608 features suggest how learning-based initiatives can support the expansion and enhancement

609 of biodiversity on private property. Ongoing and decentralized initiatives, making use of

610 diverse informal and non-formal opportunities, can aid the design and delivery of nature-

611 based solutions. They can also support policy makers, urban planners and natural resource

612 managers in reflecting on what NBS interventions are meant to achieve in the short and long

613 term. Looking at interventions not only as solutions to given problems but as learning

614 pathways can better help policy makers and practitioners to consider among competing

615 components and select those better favouring learning and change.

616 
Table 1: Summary of themes about learning activities or processes and the number and percentage $(n=42,100 \%)$ of probative interviews. The themes are interrelated and not mutually exclusive (with the exception of certification vs. certification and workshops or classes).

\begin{tabular}{|c|c|c|}
\hline Primary themes & Secondary themes & Tertiary themes \\
\hline \multirow{6}{*}{$\begin{array}{l}\text { Workshops, classes, } \\
\text { conferences }(37,88 \%)\end{array}$} & \multirow{3}{*}{ Naturescape/FortWhyte $(26,62 \%)$} & Certification $(17,40 \%)$ \\
\hline & & $\begin{array}{l}\text { Certification and } \\
\text { workshops or classes } \\
(10,24 \%)\end{array}$ \\
\hline & & Consultation $(2,5 \%)$ \\
\hline & $\begin{array}{l}\text { Universities, the city, churches or } \\
\text { conservation organizations }(15,36 \%)\end{array}$ & \\
\hline & $\begin{array}{l}\text { Manitoba Master Gardener Association } \\
(9,21 \%)\end{array}$ & \\
\hline & $\begin{array}{l}\text { Garden clubs, societies or nurseries }(7, \\
17 \%)\end{array}$ & \\
\hline \multicolumn{3}{|l|}{$\begin{array}{l}\text { Childhood experiences } \\
(31,74 \%)\end{array}$} \\
\hline \multirow{3}{*}{ Practice $(31,74 \%)$} & $\begin{array}{l}\text { Exploration, experimentation, or trial } \\
\text { and error }(21,50 \%)\end{array}$ & \\
\hline & Learning by doing $(20,48 \%)$ & \\
\hline & $\begin{array}{l}\text { Volunteering in the community (10, } \\
24 \%)\end{array}$ & \\
\hline \multirow{3}{*}{$\begin{array}{l}\text { Talking with gardeners } \\
(18,43 \%)\end{array}$} & Technical experts $(11,26 \%)$ & \\
\hline & Friends and peers $(11,26 \%)$ & \\
\hline & Family $(3,7 \%)$ & \\
\hline \multirow{4}{*}{$\begin{array}{l}\text { Resource material ( } 17 \text {, } \\
40 \%)\end{array}$} & Books and magazines $(13,31 \%)$ & \\
\hline & Internet $(4,10 \%)$ & \\
\hline & Brochures and pamphlets $(3,7 \%)$ & \\
\hline & Reading $(3,7 \%)$ & \\
\hline \multirow{2}{*}{ Observation $(10,24 \%)$} & Garden tours and field trips $(6,14 \%)$ & \\
\hline & Watching family $(4,10 \%)$ & \\
\hline
\end{tabular}


Table 2: Summary of themes about learning outcomes and the number and percentage $(n=$ $42,100 \%$ ) of probative interviews. The themes are interrelated and not mutually exclusive.

\begin{tabular}{|c|c|c|}
\hline Primary themes & Secondary themes & Tertiary themes \\
\hline \multirow{4}{*}{$\begin{array}{l}\text { Normative }(42, \\
100 \%)\end{array}$} & $\begin{array}{l}\text { Personal fulfilment } \\
\text { or identity }(32,76 \%)\end{array}$ & $\begin{array}{l}\text { Mindfulness, reflection or relaxation }(19,45 \%) \text {, } \\
\text { Happiness, gratification or creativity }(11,26 \%) \text {, } \\
\text { Sense of home }(7,17 \%) \text {, Direction, motivation or } \\
\text { focus }(5,12 \%)\end{array}$ \\
\hline & $\begin{array}{l}\text { Nature connections } \\
(31,74 \%)\end{array}$ & $\begin{array}{l}\text { Wildlife and birds }(19,45 \%) \text {, Biodiversity }(12, \\
29 \%) \text {, Balance or beauty }(5,12 \%)\end{array}$ \\
\hline & $\begin{array}{l}\text { Environmental } \\
\text { consciousness }(28, \\
67 \%)\end{array}$ & $\begin{array}{l}\text { Environmental protection or conservation }(10, \\
24 \%), \text { Stewardship }(10,24 \%) \text {, Food sovereignty } \\
(7,17 \%) \text {, Permaculture or sustainability }(3,7 \%)\end{array}$ \\
\hline & $\begin{array}{l}\text { Engaging with } \\
\text { community }(9,21 \%)\end{array}$ & Teaching or helping others $(5,12 \%)$ \\
\hline \multirow{3}{*}{$\begin{array}{l}\text { Cognitive or } \\
\text { behavioural }(42, \\
100 \%)\end{array}$} & Nature $(39,93 \%)$ & $\begin{array}{l}\text { Ecosystems }(29,69 \%) \text {, Plants }(22,52 \%), \text { Birds } \\
(19,45 \%), \text { Outdoor living and nature observation } \\
(13,31 \%)\end{array}$ \\
\hline & $\begin{array}{l}\text { Gardening }(35, \\
83 \%)\end{array}$ & $\begin{array}{l}\text { Management }(29,69 \%) \text {, Design }(16,38 \%) \\
\text { Methods }(15,36 \%) \text {, Challenges }(6,14 \%)\end{array}$ \\
\hline & $\begin{array}{l}\text { Validation or } \\
\text { empowerment }(17, \\
40 \%)\end{array}$ & \\
\hline \multirow{4}{*}{$\begin{array}{l}\text { Relational (40, } \\
95 \%)\end{array}$} & $\begin{array}{l}\text { Community building } \\
34,81 \%)\end{array}$ & $\begin{array}{l}\text { Shared interest in nature }(20,48 \%) \text {, Reciprocity } \\
\text { or gifting }(20,48 \%) \text {, Enhanced friendships }(10 \text {, } \\
24 \%) \text {, New acquaintances }(10,24 \%)\end{array}$ \\
\hline & $\begin{array}{l}\text { Family bonding }(27, \\
64 \%)\end{array}$ & $\begin{array}{l}\text { Shared interests and activities }(21,50 \%) \text {, Family } \\
\text { memories or sentiments }(9,21 \%)\end{array}$ \\
\hline & $\begin{array}{l}\text { Civic engagement } \\
(18,43 \%)\end{array}$ & $\begin{array}{l}\text { New or wider networks }(9,21 \%) \text {, Volunteering } \\
(9,21 \%) \text {, Advocacy }(8,19 \%)\end{array}$ \\
\hline & $\begin{array}{l}\text { Conflict or isolation } \\
(12,29 \%)\end{array}$ & \\
\hline
\end{tabular}




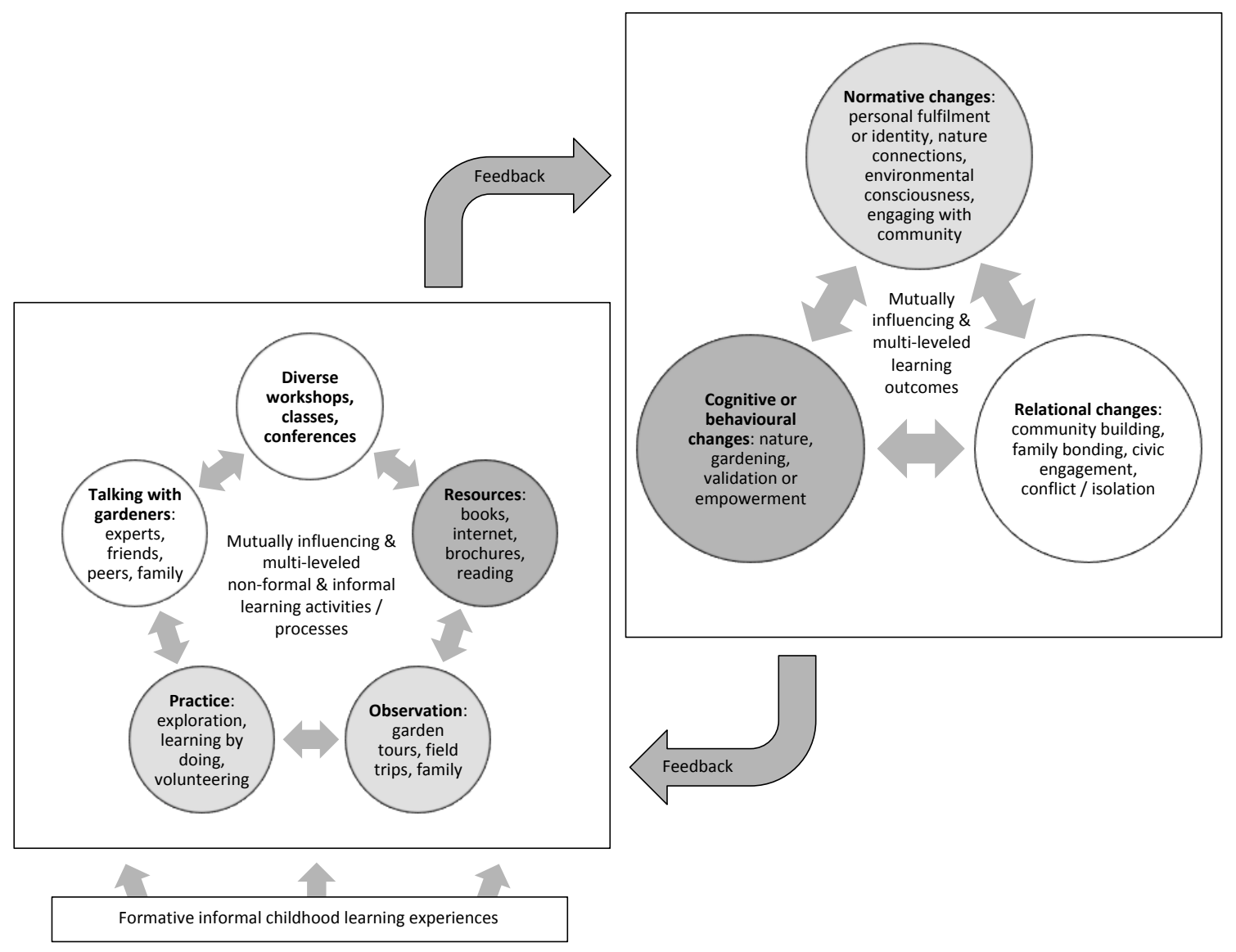

Figure 1: Multiple pathways of learning about biodiversity and sustainability in private urban gardens 
617

618

619

620

621

622

623

624

625

626

627

628

629

630

631

632

633

634

635

636

637

638

639

640

641

642

643

644

645

646

647

648

649

650

651

652

653

654

655

656

657

658

659

660

661

662

663

\section{References}

Andersson, E., S. Barthel, S. Borgström, J. Colding, T. Elmqvist, C. Folke and Å. Gren (2014). "Reconnecting cities to the biosphere: stewardship of green infrastructure and urban ecosystem services." AMBIO 43(4): 445-453.

Baldock, K. C. R., M. A. Goddard, D. M. Hicks, W. E. Kunin, N. Mitschunas, H. Morse, L. M. Osgathorpe, S. G. Potts, K. M. Robertson, A. V. Scott, P. P. A. Staniczenko, G. N. Stone, I. P. Vaughan and J. Memmott (2019). "A systems approach reveals urban pollinator hotspots and conservation opportunities." Nature Ecology \& Evolution 3(3): 363-373.

Beery, T. H., C. M. Raymond, M. Kyttä, A. S. Olafsson, T. Plieninger, M. Sandberg, M. Stenseke, M. Tengö and K. I. Jönsson (2017). "Fostering incidental experiences of nature through green infrastructure planning." Ambio 46(7): 717-730.

Bourke, R., J. O'Neill and J. Loveridge (2018). "Children's conceptions of informal and everyday learning." Oxford Review of Education 44(6): 771-786.

Buijs, A. E., T. J. M. Mattijssen, A. P. N. Van der Jagt, B. Ambrose-Oji, E. Andersson, B. H. M. Elands and M. Steen Møller (2016). "Active citizenship for urban green infrastructure: fostering the diversity and dynamics of citizen contributions through mosaic governance." Current Opinion in Environmental Sustainability 22: 1-6.

Cameron, R. W. F., T. Blanuša, J. E. Taylor, A. Salisbury, A. J. Halstead, B. Henricot and K. Thompson (2012). "The domestic garden - Its contribution to urban green infrastructure." Urban Forestry \& Urban Greening 11(2): 129-137.

Camps-Calvet, M., J. Langemeyer, L. Calvet-Mir and E. Gómez-Baggethun (2016). "Ecosystem services provided by urban gardens in Barcelona, Spain: Insights for policy and planning." Environmental Science \& Policy 62(Supplement C): 14-23.

Cleveland, D. A., N. Phares, K. D. Nightingale, R. L. Weatherby, W. Radis, J. Ballard, M. Campagna, D. Kurtz, K. Livingston, G. Riechers and K. Wilkins (2017). "The potential for urban household vegetable gardens to reduce greenhouse gas emissions." Landscape and Urban Planning 157(Supplement C): 365-374.

Corbin, J. and A. Strauss (2014). Basics Of Qualitative Research: Techniques and Procedures for Developing Grounded Theory Los Angeles, Sage.

Creswell, J. W. (2014). Research Design: Qualitative, Quantitative, and Mixed Methods Approaches. Los Angeles, Sage.

Dewaelheyns, V., E. Kerselaers and E. Rogge (2016). "A toolbox for garden governance." Land Use Policy 51(Supplement C): 191-205.

Diduck, A. P. (2010). The learning dimension of adaptive capacity: untangling the multi-level connections. Adaptive Capacity: Building Environmental Governance in an Age of Uncertainty. D. Armitage and R. Plummer. Heidelberg, Germany, Springer: 199-221. Environment Canada. (2018). "1981 to 2010 Canadian Climate Normals." Retrieved June 29, 2018, from http://climate.weather.gc.ca/climate_normals/index_e.html.

Fish, R., A. Church and M. Winter (2016). "Conceptualising cultural ecosystem services: A novel framework for research and critical engagement." Ecosystem Services 21: 208217.

Fisman, L. (2005). "The effects of local learning on environmental awareness in children: an empirical investigation." The Journal of Environmental Education 36(3): 39-50.

Frantzeskaki, N. and N. Kabisch (2016). "Designing a knowledge co-production operating space for urban environmental governance-Lessons from Rotterdam, Netherlands and Berlin, Germany." Environmental Science \& Policy 62(Supplement C): 90-98. 
Freeman, C., K. J. M. Dickinson, S. Porter and Y. van Heezik (2012). "“My garden is an expression of me": exploring householders' relationships with their gardens." Journal of Environmental Psychology 32(2): 135-143.

Galluzzi, G., P. Eyzaguirre and V. Negri (2010). "Home gardens: neglected hotspots of agrobiodiversity and cultural diversity." Biodiversity and Conservation 19(13): 36353654.

Gaston, K. J., R. A. Fuller, A. Loram, C. MacDonald, S. Power and N. Dempsey (2007). "Urban domestic gardens (XI): variation in urban wildlife gardening in the United Kingdom." Biodiversity and Conservation 16(11): 3227-3238.

Gaston, K. J., P. H. Warren, K. Thompson and R. M. Smith (2005). "Urban domestic gardens (IV): the extent of the resource and its associated features." Biodiversity \& Conservation 14(14): 3327-3349.

Gerlak, A. K., T. Heikkila, S. L. Smolinski, D. Huitema and D. Armitage (2017). "Learning our way out of environmental policy problems: A review of the scholarship." Policy Sciences.

Goddard, M. A., A. J. Dougill and T. G. Benton (2013). "Why garden for wildlife? Social and ecological drivers, motivations and barriers for biodiversity management in residential landscapes." Ecological Economics 86(Supplement C): 258-273.

Heimlich, J. E., J. D. Adams and M. J. Stern (2017). Nonformal educational settings. Urban Environmental Education Review. A. Russ and M. E. Krasny. Ithaca, United States, Cornell University Press: $115-123$.

Iojă, C. I., S. R. Grădinaru, D. A. Onose, G. O. Vânău and A. C. Tudor (2014). "The potential of school green areas to improve urban green connectivity and multifunctionality." Urban Forestry \& Urban Greening 13(4): 704-713.

Krasny, M. E., C. Lundholm, S. Shava, E. Lee and H. Kobori (2013). Urban landscapes as learning arenas for biodiversity and ecosystem services management. Urbanization, Biodiversity and Ecosystem Services: Challenges and Opportunities: A Global Assessment. T. Elmqvist, M. Fragkias, J. Goodness et al. Dordrecht, Springer Netherlands: 629-664.

Laila, E. v. L., U. Jennifer, D. Simon, L. Mathijs, D. Ben and C. Terryann (2016). "Home gardening and the health and well-being of adolescents." Health Promotion Practice 18(1): 34-43.

Lerman, S. B. and P. S. Warren (2011). "The conservation value of residential yards: linking birds and people." Ecological Applications 21(4): 1327-1339.

Lindemann-Matthies, P. and T. Marty (2013). "Does ecological gardening increase species richness and aesthetic quality of a garden?" Biological Conservation 159(Supplement C): 37-44.

Livesley, S. J., B. J. Dougherty, A. J. Smith, D. Navaud, L. J. Wylie and S. K. Arndt (2010). "Soil-atmosphere exchange of carbon dioxide, methane and nitrous oxide in urban garden systems: impact of irrigation, fertiliser and mulch." Urban Ecosystems 13(3): 273-293.

Loram, A., J. Tratalos, P. H. Warren and K. J. Gaston (2007). "Urban domestic gardens (X): the extent \& structure of the resource in five major cities." Landscape Ecology 22(4): 601-615.

Loram, A., P. Warren, K. Thompson and K. Gaston (2011). "Urban domestic gardens: the effects of human interventions on garden composition." Environmental Management 48(4): 808.

Luederitz, C., E. Brink, F. Gralla, V. Hermelingmeier, M. Meyer, L. Niven, L. Panzer, S. Partelow, A.-L. Rau, R. Sasaki, D. J. Abson, D. J. Lang, C. Wamsler and H. von 
Wehrden (2015). "A review of urban ecosystem services: six key challenges for future research." Ecosystem Services 14: 98-112.

Mattijssen, T., A. Buijs, B. Elands and B. Arts (2018). "The 'green' and 'self' in green selfgovernance - a study of 264 green space initiatives by citizens." Journal of Environmental Policy \& Planning 20(1): 96-113.

Merriam, S. B., R. S. Caffarella and L. M. Baumgartner (2007). Learning in Adulthood: A Comprehensive Guide. San Francisco, John Wiley and Sons.

Mumaw, L. (2017). "Transforming urban gardeners into land stewards." Journal of Environmental Psychology 52(Supplement C): 92-103.

Mumaw, L. and S. Bekessy (2017). "Wildlife gardening for collaborative public-private biodiversity conservation." Australasian Journal of Environmental Management 24(3): 242-260.

Niemelä, J. (2014). "Ecology of urban green spaces: The way forward in answering major research questions." Landscape and Urban Planning 125(Supplement C): 298-303.

Niinemets, Ü. and J. Peñuelas (2008). "Gardening and urban landscaping: significant players in global change." Trends in Plant Science 13(2): 60-65.

Paradise, R. and B. Rogoff (2009). "Side by side: Learning by observing and pitching in." Journal of the Society for Psychological Anthropology 37(1): 102-138.

Peterson, M. N., B. Thurmond, M. McHale, S. Rodriguez, H. D. Bondell and M. Cook (2012). "Predicting native plant landscaping preferences in urban areas." Sustainable Cities and Society 5(Supplement C): 70-76.

Pickett, S. T. A., M. L. Cadenasso, J. M. Grove, C. G. Boone, P. M. Groffman, E. Irwin, S. S. Kaushal, V. Marshall, B. P. McGrath, C. H. Nilon, R. V. Pouyat, K. Szlavecz, A. Troy and P. Warren (2011). "Urban ecological systems: Scientific foundations and a decade of progress." Journal of Environmental Management 92(3): 331-362.

Raymond, C. M., P. Berry, M. Breil, M. R. Nita, N. Kabisch, M. de Bel, Enzi, V., N. Frantzeskaki, D. Geneletti, M. Cardinaletti, L. Lovinger, C. Basnou, A. Monteiro, H. Robrecht, G. Sgrigna, L. Munari and C. Calfapietra (2017). An Impact Evaluation Framework to Support Planning and Evaluation of Nature-based Solutions Projects. Report prepared by the EKLIPSE Expert Working Group on Nature-based Solutions to Promote Climate Resilience in Urban Areas. Wallingford, United Kingdom.

Raymond, C. M., B. A. Bryan, D. H. MacDonald, A. Cast, S. Strathearn, A. Grandgirard and T. Kalivas (2009). "Mapping community values for natural capital and ecosystem services." Ecological Economics 68(5): 1301-1315.

Rodela, R. (2014). "Social learning, natural resource management, and participatory activities: A reflection on construct development and testing." NJAS - Wageningen Journal of Life Sciences 69: 15-22.

Russ, A. and M. E. Krasny (2017). Educational trends. Urban Environmental Education Review. A. Russ and M. E. Krasny. Ithaca, United States, Cornell University Press: 288-296.

Salomon, G. and D. N. Perkins (1998). "Individual and social aspects of learning." Review of Research in Education 23(1): 1-24.

Schwarz, N., M. Moretti, M. N. Bugalho, Z. G. Davies, D. Haase, J. Hack, A. Hof, Y. Melero, T. J. Pett and S. Knapp (2017). "Understanding biodiversity-ecosystem service relationships in urban areas: A comprehensive literature review." Ecosystem Services 27: 161-171.

Seto, K. C., B. Güneralp and L. R. Hutyra (2012). "Global forecasts of urban expansion to

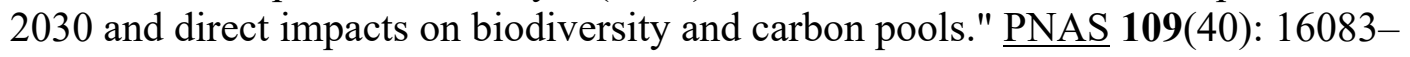
16088. 
Shaw, A., K. K. Miller and G. Wescott (2017). "Australian native gardens: Is there scope for a community shift?" Landscape and Urban Planning 157(Supplement C): 322-330.

Shwartz, A., A. Turbé, R. Julliard, L. Simon and A.-C. Prévot (2014). "Outstanding challenges for urban conservation research and action." Global Environmental Change 28(Supplement C): 39-49.

Smith, R. M., K. J. Gaston, P. H. Warren and K. Thompson (2005). "Urban domestic gardens (V): relationships between landcover composition, housing and landscape." Landscape Ecology 20(2): 235-253.

Sperling, C. D. and C. J. Lortie (2010). "The importance of urban backgardens on plant and invertebrate recruitment: a field microcosm experiment." Urban Ecosystems 13(2): 223-235.

Statistics Canada. (2017). "Census Profile, 2016 Census." Retrieved October 11, 2017, from http://www12.statcan.gc.ca/census-recensement/2016/dp-pd/prof/index.cfm?Lang=E.

Steffen, W., J. Rockström, K. Richardson, T. M. Lenton, C. Folke, D. Liverman, C. P. Summerhayes, A. D. Barnosky, S. E. Cornell, M. Crucifix, J. F. Donges, I. Fetzer, S. J. Lade, M. Scheffer, R. Winkelmann and H. J. Schellnhuber (2018). "Trajectories of the Earth System in the Anthropocene." Proceedings of the National Academy of Sciences 115(33): 8252.

Suškevičs, M., T. Hahn, R. Rodela, B. Macura and C. Pahl-Wostl (2017). "Learning for social-ecological change: a qualitative review of outcomes across empirical literature in natural resource management." Journal of Environmental Planning and Management: 1-28.

United Nations Population Division (2014). World Urbanization Prospects: The 2014 Revision, Highlights, United Nations, Department of Economic and Social Affairs, Population Division.

van Heezik, Y., C. Freeman, S. Porter and K. J. M. Dickinson (2013). "Garden Size, Householder Knowledge, and Socio-Economic Status Influence Plant and Bird Diversity at the Scale of Individual Gardens." Ecosystems 16(8): 1442-1454.

van Heezik, Y. M., K. J. M. Dickinson and C. Freeman (2012). "Closing the gap: communicating to change gardening practices in support of native biodiversity in urban private gardens." Ecology and Society 17(1).

Wals, A. E. J., Ed. (2007). Social Learning Towards a Sustainable World: Principles, Perspectives, and Praxis. Wageningen, The Netherlands, Wageningen Academic Publishers. 